\title{
Impaired Antibody Response to Intravenous Immunization in Sickle Cell Anemia
}

\author{
Allen D. Schwartz ${ }^{[24]}$ and Howard A. Pearson \\ Department of Pediatrics, Yale University School of Medicine and Yale-New Haven Hospital, New Haven, Connecticut, USA
}

\begin{abstract}
Extract
The spleen is essential for the formation of antibody in response to intravenously administered particulate antigen. Therefore, this splenic function was investigated in a number of children with sickle cell anemia. Following intravenous administration of $1.0 \mathrm{ml}$ sheep red cells, heterophile antibody titers were determined at $0,7,14$, and 21 days. One normal ( $\mathrm{Hgb} \mathrm{AA}$ ), one sickle trait ( $\mathrm{Hgb} \mathrm{AS}$ ), and two sickle-thalassemia (Hgb SSF) children had significant rises in heterophile titers with at least a 2 -fold rise in 7 days and a minimum of 4-fold rise by day 14. This is comparable to responses of normal individuals previously reported. Five Hgb SS children had minimal antibody response with none having a rise in titer at 7 days. Three of these children had palpable spleens but no splenic visualization on scans. Two children received transfusions which restored splenic uptake of radiocolloid before antigenic challenge. These children also failed to form antibody. One child with sickle cell anemia received the same dose of sheep erythrocytes intramuscularly and had a significant antibody response comparable to normals.
\end{abstract}

\section{Speculation}

The defect of immunologic function in children with sickle cell anemia is similar to that described in asplenic individuals. This may be an important determinant of the increased susceptibility to infection in children with this disorder and their predisposition to overwhelming pneumococcal septicemia.

\section{Introduction}

We recently reported [14] a state of impaired splenic reticuloendothelial activity ("functional asplenia") in children with sickle cell anemia. This defect was suggested by observation of the hematologic changes of splenic hypofunction, and was confirmed by an isotopic scanning technique using ${ }^{99 m} \mathrm{Tc}$-sulfur colloid. Functional asplenia was found to be reversible in some patients by transfusions of normal red cells sufficient to reduce the numbers of sickle cells below $50 \%$ [13].

The fact that the great majority of children with sickle cell disease have abnormal splenic function has important clinical implications. These children are unusually susceptible to overwhelming septicemia $[8,16]$, a predisposition also seen in the young, splenectomized child $[2,4-6,10,11]$. The basis of susceptibility to this type of infection is not completely clear, but it is due, at least in part, to a failure of the spleen's unique role in clearing bacteria from the blood of the nonimmune individual [21]. Further, the spleen appears to be essential for the formation of antibody in response to small doses of intravenously administered particulate antigen $[17,18]$. The immunologic capacity of children with sickle cell disease has been reported to be 
Table I. Hemagglutination titers to sheep red blood cells

\begin{tabular}{cllllll}
\hline $\begin{array}{c}\text { Pa- } \\
\text { tient }\end{array}$ & Diagnosis & Day0 & Day 7 & Day 14 & Day 21 $\begin{array}{c}\text { Maxi- } \\
\text { mum } \\
\text { tube } \\
\text { rise }\end{array}$ \\
\hline 1 & AA & $1: 7$ & $1: 56$ & $1: 112$ & $1: 112$ & 4 \\
2 & AS & $1: 7$ & $1: 112$ & $1: 224$ & $1: 56$ & 5 \\
3 & S-Thal & $1: 7$ & $1: 14$ & $1: 28$ & $1: 28$ & 2 \\
4 & S-Thal & 0 & $1: 224$ & $1: 224$ & $1: 112$ & 6 \\
5 & SS & $1: 7$ & $1: 7$ & $1: 28$ & $1: 28$ & 2 \\
6 & SS & $1: 56$ & $1: 56$ & $1: 56$ & $1: 56$ & 0 \\
7 & SS & 0 & 0 & $1: 7$ & $1: 7$ & 1 \\
8 & SS (transfused) & $1: 56$ & $1: 56$ & $1: 112$ & $1: 112$ & 1 \\
9 & SS (tranffused) & $1: 56$ & $1: 56$ & $1: 112$ & $1: 224$ & 2 \\
10 & SS (intramuscular & $1: 7$ & $1: 28$ & $1: 112$ & $1: 56$ & 4 \\
& challenge) & & & & & \\
\hline
\end{tabular}

1AA: Normal hemoglobin. AS: Sickle trait. S-thal: Sickle- $\beta$-thalassemia. SS Homozygous hemoglobin S disease.

normal; however, studies of their response to intravenous antigen have not been carried out. Therefore, this splenic function was investigated in a number of children with sickle cell anemia and functional asplenia, and in patients with other hemoglobin $\mathrm{S}$ disorders who had normally functioning spleens.

\section{Materials and Methods}

A total of 10 children, 2-15 years of age, were studied. Six of these had homozygous hemoglobin S disease (Hgb SS). Two adolescents, 13-15 years of age, did not have palpable spleens. They were presumably asplenic owing to autoinfarction. The other patients with $\mathrm{Hgb}$ SS disease ranged in age from 2 to 6.5 years and had palpably enlarged spleens. The remaining subjects included one child with sickle trait ( $\mathrm{Hgb} \mathrm{AS}$ ), one with normal hemoglobin (Hgb AA), and two siblings with sickle- $\beta$ (S- $\beta$ )-thalassemia (Hgb SSF). The nature of the study was explained in detail and informed parental consent was obtained in accordance with the provisions set forth in the Declaration of Helsinki.

All of the children with Hgb SS disease, including those with palpable spleens, had no splenic uptake of the ${ }^{99 m}$ Tc-sulfur colloid. The two children with sickle- $\beta$-thalassemia had uptake of the radiocolloid by their enlarged spleens demonstrated by scan.

One milliliter of a $25 \%$ suspension of sheep erythrocytes in saline was administered intravenously to all subjects but one. The exception was a 3-year-old child with $\mathrm{Hgb}$ SS disease who received the same dose of sheep red cells by intramuscular injection.

Transfusions of normal human red blood cells were administered to two of the children with Hgb SS disease. When the ability of the spleen to take up radiocolloid was established, they were challenged intravenously with sheep erythrocytes.
Serum heterophile titer was determined just prior to challenge and at weekly intervals for the following 21 days. Heterophile testing was performed in a conven tional manner, utilizing a $2 \%$ suspension of washed sheep red cells added to serial dilutions of the patients sera. After incubation at room temperature for $2 \mathrm{hr}$ the degree of agglutination was determined macroscop. ically.

\section{Results}

Table I lists the heterophile titers on all of the pa tients studied. Figures 1 and 2 depict the rises in anti body titers compared with values obtained by others in normal individuals $[17,18]$. In our studies, one norma] child, one child with sickle trait, and two childrer with $\mathrm{S}$ - $\beta$-thalassemia had significant increases in heter

\section{ANTIBODY RESPONSE TO \\ INTRAVENOUSLY ADMINISTERED SHEEP RED CELLS}

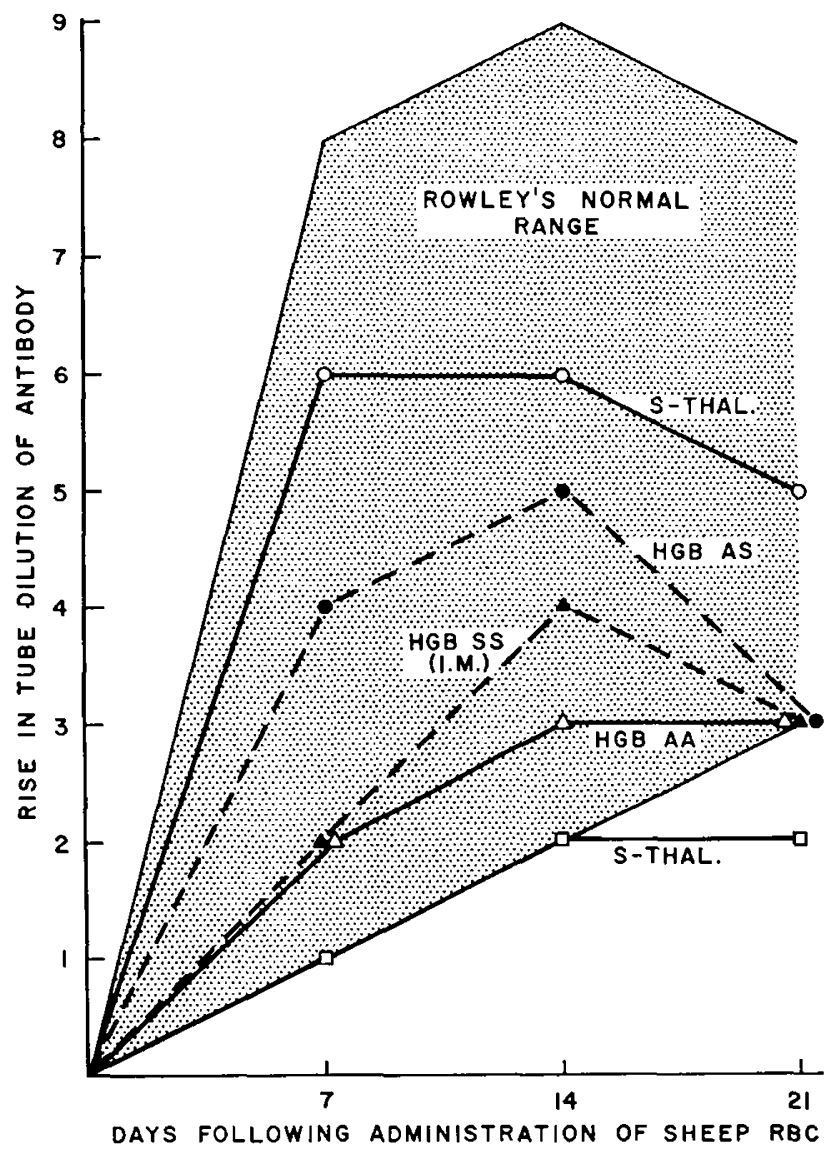

Fig. 1. Antibody response to intravenously administered shee] red cells in control patients. S-thal.: Sickle- $\beta$-thalassemia. HGl AS: Sickle trait. HGB SS: Homozygous hemoglobin $S$ disease HGB AA: normal hemoglobin. 
ophile titers. At least a 2-fold (1-tube) rise in heterophile antibody titer was seen by day 7 , with a minimum of a 4-fold (2-tube) rise by day 14 . These results are comparable to values obtained in normal individuals. The child with $\mathrm{Hgb}$ SS disease who received sheep erythrocytes intramuscularly also had a normal response.

All five children with Hgb SS disease who received sheep red cells intravenously had minimal antibody response, for none demonstrated an increased titer in 7 days, and the maximum increase observed was only a 4-fold (2-tube) rise. There were no differences observed in the responses of the children with $\mathrm{Hgb}$ SS disease whose splenic uptake of radiocolloid had been established following transfusions and those who had not been transfused.

Base line antibody titers for half of the children with sickle cell anemia were 1:56. This is higher than base line titers of the children with functioning spleens (Table I). A similar observation was made by Rowley [18] in his splenectomized patients.

\section{Discussion}

Splenectomized monkeys have been demonstrated to have a normal antibody response to subcutaneous tularemia vaccine [20]. The splenectomized rat has a normal antibody response to particulate antigen when challenged intraperitoneally, intraportally, or intradermally. However, this animal has been shown to be incapable of responding to the same dose and type of antigen administered intravenously [18]. The route by which antigen is administered thus appears to be a critical factor in antibody formation in the asplenic animal.

Splenectomized human beings also have been demonstrated to have normal immunologic responses when antigen is administered via intramuscular or subcutaneous routes [19]. In 1950, Rowley demonstrated that splenectomized man, when challenged with a single intravenous injection of sheep red cells, failed to respond with a significant rise in heterophile antibody titer [18]. This defect has also been demonstrated in children with hereditary splenic hypoplasia [9]. These findings indicate that in the human, also, the spleen is essential for the processing and perhaps synthesis of antibody in response to particulate antigen delivered by the intravenous route.

Children with sickle cell anemia have normal levels of serum diphtheria toxin-neutralizing activity and have also been shown to have normal responses to

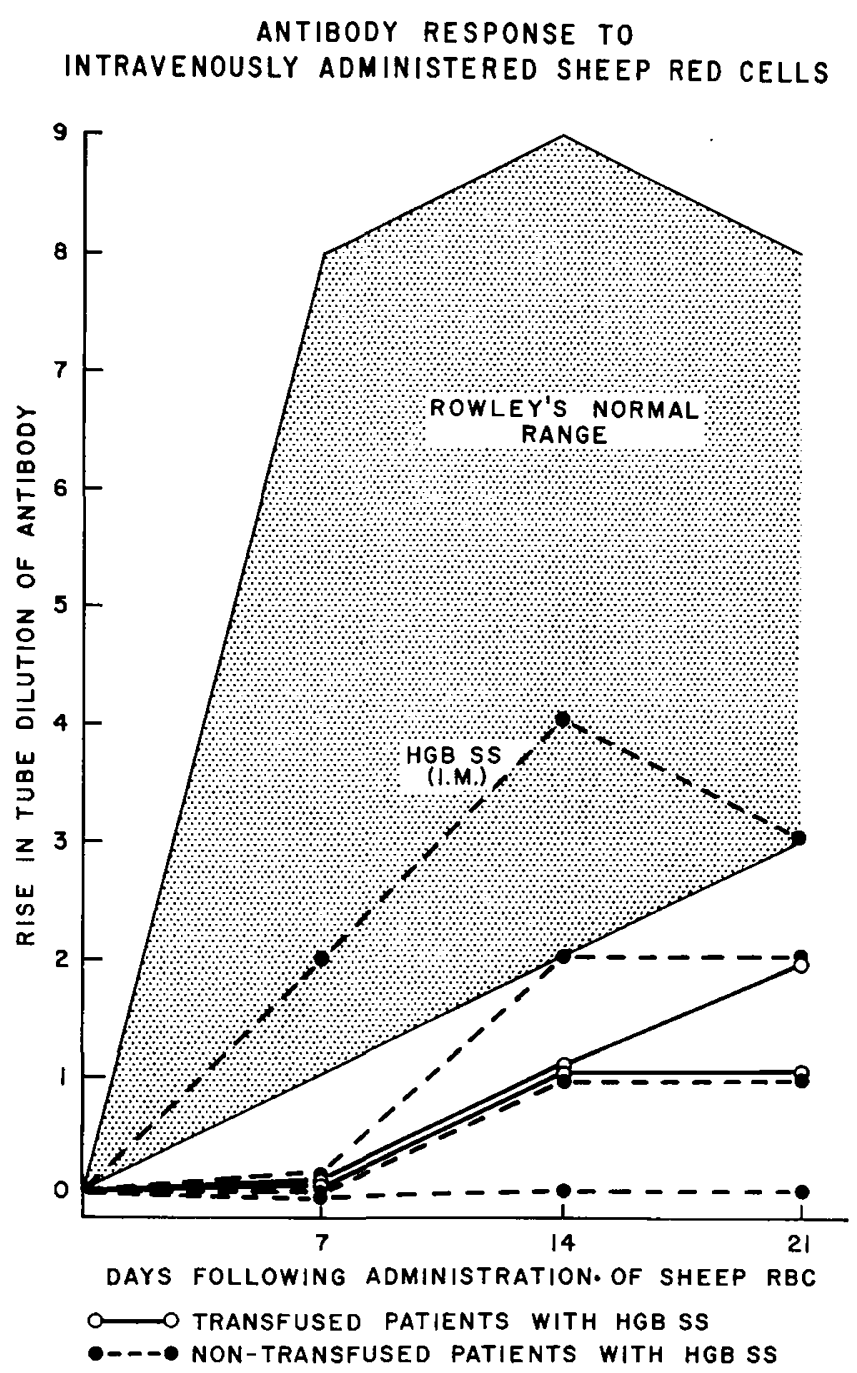

Fig. 2. Antibody response to sheep red cells in patients with sickle cell anemia. HGB SS: Homozygous hemoglobin $S$ disease.

intradermal Salmonella vaccine [15]. In our study, the one sickle cell anemia patient who received sheep erythrocytes by intramuscular injection had a normal antibody response. This normal response confirms that there is no generalized inability to respond to antigenic challenge in this disease.

A syndrome of fulminant pneumococcal septicemia and meningitis has been well documented in the young hyposplenic [9] and splenectomized child [2, $4-6,10,11]$. Infants with sickle cell anemia share this same predisposition to overwhelming infection $[8,16]$. The spleens of older patients with sickle cell anemia are shrunken and fibrotic as a consequence of progressive vascular occlusion and infarction [3], resulting in autosplenectomy. However, young children with sickle cell anemia who develop pneumococcal sepsis often 
have enlarged spleens. This apparent paradox was resolved by our studies which described a state of "functional asplenia" in these young children [13, 14].

Of interest were the findings in two siblings with S- $\beta$-thalassemia. They had normal splenic reticuloendothelial function as indicated by an absence of Howell-Jolly bodies in their blood and by normal ${ }^{99 \mathrm{~m}} \mathrm{Tc}$ sulfur colloid scans. These children also had normal antibody responses to intravenous sheep erythrocytes. Although both children had hemoglobin electrophoresis patterns comparable with those in sickle cell anemia, their true genotypes were established by family studies which revealed their mother to have $\beta$-thalassemia trait. In general, $S-\beta$-thalessemia is not as severe in clinical or hematologic manifestations as $\mathrm{Hgb} \mathrm{SS}$ disease [12]. This often cannot be explained by the hemoglobin patterns. In our cases, the levels of hemoglobin $\mathrm{F}$ observed were not in the markedly elevated range which has been shown to inhibit sickling in vitro [1]. An increased predisposition to pneumococcal septicemia has not been noted in patients with $S-\beta$-thalassemia [16], although one case has been recently reported by Kabins and Lerner [8].

We believe that functional asplenia results from a sludging of sickled cells in the microcirculation of the spleen. The low $\mathrm{pH}$, low $\mathrm{P}_{\mathrm{O}_{2}}$, and a slow circulation within the splenic cords facilitate the sickling process. A mass of sickled cells produces a relative obstruction to blood flow, resulting in a diversion of flow through arteriovenous shunts $[7,22]$. The reticuloendothelial elements of the spleen are thus bypassed by much of the splenic blood flow, resulting in functional asplenia. When sickled cells are replaced by normal cells, the normal splenic circulation is restored.

However, visualization of the spleen by an isotopic scanning procedure following red cell transfusion could not be equated with normal immunologic function. Transfused sickle cell anemia patients whose spleens appeared on scan showed defective antibody responses to sheep erythrocytes comparable to other sickle cell anemia and asplenic patients.

This apparent dissociation of functions may be due to differences in particle size. The technetium-sulfur colloid consists of roughly spherical particles approximately $1 \mu$ in diameter, while sheep red cells have diameters of about $7 \mu$. It is possible that the smaller colloidal particles were able to traverse the splenic cords and sinusoids more easily than the larger sheep red cells. Alternatively, restoration of the phagocytic function might be effected without returning the ability to produce antibody. This latter possibility would neces- sitate invoking mechanisms more complex than a mechanical shunting phenomenon.

\section{Summary}

Most young children with sickle cell anemia have functional asplenia, the paradox of impaired reticuloendothelial activity of anatomically enlarged spleens. This defect, suggested by hematologic findings, was proven by isotopic scanning using ${ }^{99 \mathrm{~m}} \mathrm{Tc}$-sulfur colloid. In addition, this defect is reversible in some patients by red cell transfusions.

Children with sickle cell anemia showed defective antibody responses to intravenously administered sheep crythrocytes. One child with sickle cell anemia had a normal antibody response to intramuscular challenge. This same defect of immunologic function is identical to that described in asplenic individuals.

Visualization of the spleen by ${ }^{99 \mathrm{~m}} \mathrm{Tc}$-sulfur colloid following red cell transfusions could not be equated to return of immunologic function, indicating a dissociation of at least two functions of the spleen, that of clearance of radiocolloid and of immunologic response.

\section{References and Notes}

1. Charache, S., and Conley, C. L.: Rate of sickling of red cells during oxygenation of blood from persons with various sickling disorders. Blood, 24: 25 (1964).

2. Diamond, I. K.: Splenectomy in childhood and the hazard of overwhelming infection. Pediatrics, 43: 886 (1969).

3. Drgss, L. W.: Siderofibrosis of the spleen in sickle cell anemia. J. Amer. Med. Ass., 104: 538 (1935).

4. Ellis, E. F., And SMith, R. T.: The role of the spleen in immunity. Pediatrics, 37: 111 (1966).

5. Eraklis, A. J., Kevy, S. V., Diamond, L. K., and Gross, R. E.: Hazard of overwhelming infection after splenectomy in childhood. New Engl. J. Med., 276: 1125 (1967).

6. Erickson, W. D., Burgert, E. O., and Lynn, H. B.: The hazard of infection following splenectomy in children. Amer. J. Dis. Child., 116: 1 (1968).

7. Garnetr, E. S., Goddard, B. A., Marklex, D., ANd Webber, C. E.: The spleen as an arteriovenous shunt. Lancet, $i: 386$ (1969).

8. Kabins, S. A., ANd Lerner, C.: Fulminant pneumococcemia and sickle cell anemia. J. Amer. Med. Ass., 211: 467 (1970).

9. Kevy, S. V., Tefre, M., Vawter, G. F., ANd Rosen, F. S.: Hereditary splenic hypoplasia. Pediatrics, 42: 752 (1968).

10. KING, H., AND SCHUMACHER, H. B.: Susceptibility to infection after splenectomy performed in infants. Ann. Surg., 136: 239 (1952).

11. McCracken, G. H., and Drckerman, J. D.: Septicemia and disseminated intravascular coagulation. Occurrence in four asplenic children. Amer. J. Dis. Child., 118: 431 (1969).

12. Pearson, H. A.: Hemoglobin S-thalassemia syndrome in Negro children. Ann. N. Y. Acad. Sci., 165: 83 (1969). 
13. Pearson, H. A., Cornelius, E. A., Schwartz, A. D., Zelson, J. H., Wolfson, S. L., ANd Spencer, R. P.: Transfusion reversible functional asplenia in young children with sickle cell anemia. New Engl. J. Med., 283: 334 (1970).

14. Pearson, H. A., Spencer, R. P., and Cornelius, E. A.: Functional asplenia in sickle-cell anemia. New Engl. J. Med., 281: 923 (1969).

15. Robbins, J. B., and Pearson, H. A.: Normal response of sickle cell patients to immunization with Salmonella vaccines. J. Pediat., 66: 877 (1965).

16. Robinson, M. G., and Watson, R. J.: Pneumococcal meningitis in sickle-cell anemia. New Engl. J. Med., 274: 1006 (1966).

17. Rowley, D. A.: The effect of splenectomy on the formation of circulating antibody in the adult male albino rat. J. Immunol., 64: 289 (1950).

18. RowLEY, D. A.: The formation of circulating antibody in the splenectomized human being following intravenous injection of heterologous erythrocytes. J. Immunol., 65: 515 (1950).
19. Saslaw, S., Bouroncle, B. A., Well, R. L., and Doan, C. A.: Studies on the antibody response in splenectomized persons. New Engl. J. Med., 261: 120 (1959).

20. Saslaw, S., and Carlisle, $H$. N.: Antibody response in splen. ectomized monkeys. Proc. Soc. Exp. Biol. Med., 116: 738 (1964).

21. Schulkind, M. L., Ellis, E. F., ANd Smixh, R. T.: Effect of antibody upon clearance of $\mathrm{I}^{125}$ labelled pneumococci by the spleen and liver. Pediat. Res., 1: 178 (1967).

22. Williams, R. C.: The microscopic structure and behavior of spleen autografts in rabbits. Amer. J. Anat., 87: 495 (1950).

23. Supported in part by Public Health Service Research Grant No. HD-00177-04.

24. Requests for reprints should be addressed to: Allen D. SchwarTz, M.D., Department of Pediatrics, Yale-New Haven Hospital, New Haven, Conn. 06510 (USA).

25. Accepted for publication April 26, 1971. 